\title{
Is the Use of a Stapler for Ileocolic Anastomosis Linked to Anastomotic Leakage?
}

\author{
Ileokolik Anastomozda Stapler Kullanımı Anastomoz Kaçağı ile Ilişkili midir? \\ Tolga Olmez $\odot$, Orhan Uzun $\odot$, Omer Ozduman $\odot$, Selcuk Gulmez $\odot$, Ayhan Oz $\odot$ \\ Erdal Polat $\odot$, Mustafa Duman $\odot$
}

University of Health Sciences, Department of Gastroenterological Surgery, Kartal Kosuyolu High Speciality and Training Hospital, Istanbul, Turkey

Received: 19.06.2020 / Accepted: 08.07.2020 / Published Online: 30.09.2020

Cite as: Olmez T, Uzun O, Ozduman O, Gulmez S, Oz A, Polat E, Duman M. Is the use of a stapler for ileocolic anastomosis linked to anastomotic leakage? Med J Bakirkoy 2020;16(3):256-62

\section{ABSTRACT}

Objective: The effect of stapler use on anastomotic leakage $(A L)$ is uncertain in right hemicolectomy and ileocolic anastomosis. In this study, the effect of hand -sewn or assisted anastomosis performed in our center on anastomotic leakage will be investigated and short-term mortality results will be presented.

Method: The present study was planned as a retrospective review of the medical charts of patients who underwent right hemicolectomy and an ileocolic anastomosis for the treatment of right colon cancer. Patients 18 years and older, elective surgeries were included in the study. Emergency surgeries were excluded. lleocolic anastomosis performed with staples or using hand-sewn technique was recorded. Anastomotic leakage and mortality rates at 1., and 6. postoperative months were compared.

Results: Of the 101 patients who underwent right hemicolectomy for a right colon adenocarcinoma, 66 (65.3\%) underwent hand-sewn anastomosis and 35 (34.7\%) ileocolic anastomosis using staplers. Anastomotic leakage developed in one patient (1.5\%) in the hand-sewn group and in two patients (5.7\%) in the stapled anastomosis group, although the difference was not statistically significant ( $p=0.23)$. Mortality rates at 1 month and 6 months did not differ significantly between the groups.

Conclusion: The present study shows that a stapled ileocolic anastomosis after a right hemicolectomy doesn't increase the risk of anastomotic leakage, and also has not any unfavorable effect on mortality in the short term.

Keywords: right hemicolectomy, ileocolic anastomosis, anastomotic leakage

öz

Amaç: Sağ hemikolektomi ve ileokolik anastomozda stapler kullanımının anastomoz kaçağı (AK) üzerine etkisi belirsizdir. Bu çalışmada, merkezimizde, anastomozunstapler yardımlı veya elle yapılmış olmasının anastomoz kaçağı üzerine etkisi araştırılacak ve kısa dönem mortalite sonuçları sunulacaktır.

Yöntem: Bu çalışma, retrospekif bir çalıșma olarak, sağ kolon veya hepatic fleksura kanseri nedeniyle sağ hemikolektomi ve ileokolik anastomoz yapılan hastaların dosyalarının taranması şeklinde planlandı. On sekiz yaş ve üzeri hastalar, elektif ameliyatlar çalıșmaya dâhil edildi. Acil ameliyatlar çalıșma dıșı bırakıldı. ileokolik anastomoz tekniği stapler ile veya elle dikiș olarak kayıt edildi. AK, 1. ve 6. aydaki mortalite oranları bu iki grupta karşılaştıııldı.

Bulgular: Ocak 2013 ile Aralık 2018 arasında sağ kolon adenokarsinoması nedeniyle sağ hemikolektomi yapılan toplam 101 hastadan 66 $(65,3 \%)$ hastaya elle dikiş ile anastomoz yapılırken $35(34,7 \%)$ hastanın ileokolik anastomozu stapler ile yapıldı. Postoperative komplikasyon gelişimi ve patolojik sonuçlar bakımından gruplar arası istatiksel olarak fark yoktu. Elle dikiş anastomozda 1 (1,5\%), stapler anastomozda ise $2(5,7 \%)$ hastada AK gelişti, ancak bu fark istatiksel olarak anlamlı değildi $(p=0,23)$. Sadece intraoperative kan transfüzyonu anastomoz kaçağı için risk faktörü olarak saptandı $(p=0,002)$. Bir aylık ve 6 aylık mortalite oranlarında da gruplar arasında istatiksel olarak anlamlı fark yoktu.

Sonuç: Bu çalıșma bize gösterdiki, sağ hemikolektomi sonrası ileokolik anastomozdastapler kullanımı AK riskini arttırmamaktadır. Ayrıca kısa dönem mortalite üzerine de olumsuz etkisi yoktur. Son yıllarda yapılmış ve AK için stapleri suçlayıcı çalışmaların aksine biz ileokolik anastomozda staplerin güvenle kullanılabileceğini düşünüyoruz.

Anahtar kelimeler: sağ hemikolektomi, ileokolik anastomoz, anastomoz kaçağı

Corresponding Author:

tolgaolmez@gmail.com
T. Olmez 0000-0001-6145-6130

O. Uzun 0000-0001-6550-0936

0. Ozduman 0000-0002-6527-506X

S. Gulmez 0000-0001-9719-1904
A. $0 z$ 0000-0003-1383-3573

E. Polat 0000-0002-9463-9846

M. Duman 0000-0002-0276-0543

(c) Telif hakkı Sağlık Bilimleri Üniversitesi Bakırköy Dr. Sadi Konuk Eğitim ve Araştırma Hastanesi'ne aittir. Logos Tıp Yayıncılık tarafindan yayınlanmaktadır. Bu dergide yayınlanan bütün makaleler Creative Commons Atff-GayriTicari 4.0 Uluslararası Lisansı ile lisanslanmıştır.

C Copyright Health Sciences University Bakırköy Sadi Konuk Training and Research Hospital. This journal published by Logos Medical Publishing. Licenced by Creative Commons Attribution-NonCommercial 4.0 International (CC BY) 


\section{INTRODUCTION}

Anastomotic leakage continues to be an important cause of morbidity and mortality following colonic resection. The rates of anastomotic leakage remain stable, despite advances in surgical techniques for the treatment of colon cancer. Previous studies report anastomotic leakage rates of as high as 7.5\% following colon cancer surgery ${ }^{(1-3)}$.

Various risk factors have been described for anastomotic leakage, and studies have endeavored to improve techniques of anastomosis ${ }^{(4-8)}$. The risk factors for anastomotic leakage may be related to the patient or the surgical technique. Previous studies have identified the male gender, obesity, smoking, poor nutritional status and diabetes mellitus as risk factors for anastomotic leakage ${ }^{(6,9,10)}$.

A large number of studies have been conducted on techniques of anastomosis. Studies on the development of anastomotic leakage comparing stapled and hand-sewn ileocolic anastomoses have yielded controversial results. In a Cochrane review of 825 patients with colon cancer conducted in 2011, the rate of anastomotic leakage was found to be lower in those undergoing stapled anastomosis than in those undergoing hand-sewn anastomosis ${ }^{(11)}$. In a Danish study involving 1,414 patients, the rate of anastomotic leakage was found to be higher in patients undergoing stapled anastomosis ${ }^{(12)}$.

According to current data, the effect of stapled anastomosis in a right hemicolectomy on anastomotic leakage remains uncertain. The present study evaluates the effect of stapled versus hand-sewn anastomosis on anastomotic leakage in patients undergoing right hemicolectomy and an ileocolic anastomosis in our center, and presents mortality outcomes in the short term.

\section{MATERIALS and METHOD}

The present retrospective cohort study is a review of patients who underwent right hemicolectomy and ileocolic anastomosis due to cancer of the right colon and hepatic flexure in a gastroenterological surgery clinic. The study was approved by the local ethics committee of the hospital (number 2019.2/10-
161). Patients aged 18 years and older who underwent right hemicolectomy and ileocolic anastomosis due to cancer of the right colon and hepatic flexure (with or without hepatic metastasectomy), patients with an Eastern Cooperative Oncology Group (ECOG) performance status of $\leq 3$ and those undergoing elective surgery were included in the study. Patients with a pathological diagnosis other than adenocarcinoma, patients undergoing R1/R2 resection or palliative and emergency surgery were excluded.

The data of the patients who underwent surgery between January 2013 and December 2018 were retrieved from the hospital automated system and the archived records. All operations were performed by or under the supervision of gastroenterological surgeons. Patients with anastomotic leakage, those with a confirmed diagnosis of anastomotic leakage who required radiological imaging or surgery after developing symptoms of peritonitis within 30 days of surgery were not included in the study.

The patients were first divided into two groups according to the anastomotic technique employed (stapled or hand-sewn). Then, the demographic data and mortality rates of the patients at postoperative 1 month and 6 months in both groups were compared. The body mass index (BMI), hematocrit ( $\mathrm{Hct}$ ), albumin, creatinine and C-reactive protein (CRP) levels of patients within one week prior to surgery were recorded. Patients who had smoked in the last one month were classified as active smokers. End-toside or side-to-side anastomoses were performed using both stapled and hand-sewn techniques ${ }^{(13,14)}$. In the hand-sewn technique, anastomosis was performed using a double-layer suture in a standard manner. Extracorporeal anastomosis was performed in all laparoscopic interventions.

Patients who had previously undergone abdominal surgery for any reason, and those who had received neoadjuvant chemotherapy were recorded. Charlson's comorbidity index (CCl) was used to define comorbidity ${ }^{(15)}$. In addition, length of hospital stay, preoperative FEV1, Nutritional Risk Screening (NRS 2002) and American Society of Anesthesiologists (ASA) scores were recorded. Data on open versus laparoscopic approach, operation time and perioperative blood transfusion were recorded. Standard 
right hemicolectomy involved the ligation of the right branches of the middle colic vessels, while extended right hemicolectomy involved the ligation of the middle colic vessels at their origins. The pathological stage of the patients was determined according to the guidelines of the 8th edition of the American Joint Committee on Cancer (AJCC) Colon and Rectum Staging Manual.

Continuous variables with normal distribution were presented as mean \pm standard deviation (SD). Categorical variables were expressed as numbers and percentages. The clinical variables were compared using a Student's t-test and a Pearson's Chisquare test. A Mann-Whitney $U$ test was used to compare continuous variables. A $p$ value less than 0.05 was considered statistically significant in all tests. The statistical analysis was performed using the SPSS version 25.0 (IBM, Armonk, NY) software package.

\section{RESULTS}

A total of 101 patients underwent right hemicolectomy due to adenocarcinoma of the right colon between January 2013 and December 2018, while 66 (65.3\%) patients underwent hand-sewn, and 35 (34.7\%) stapled ileocolic anastomosis. Of the study patients, $52.5 \%$ were male, the mean BMI was 27.7 $\mathrm{kg} / \mathrm{m}^{2}, 30.6 \%$ were smokers and $20.7 \%$ had a past history of abdominal surgery.

The $\mathrm{CCl}$ was $\geq 1$ in $45.6 \%$ of the patients, and this rate was higher in the stapled than in the hand-sewn anastomosis group $(p=0.011)$. Preoperative FEV1 was lower in the stapled anastomosis group $(p=0.003)$, while other parameters that could be related to complications did not differ significantly between the groups. A comparison of the demographic data and clinical characteristics of patients of the stapled and hand-sewn anastomosis groups is presented in Table 1.

Table 1. Baseline characteristics of patients and method of anastomosis.

\begin{tabular}{|c|c|c|c|c|}
\hline & $\begin{array}{l}\text { Number of patients } \\
(n=101)\end{array}$ & $\begin{array}{l}\text { Hand-sewn anastomosis } \\
\qquad(n=66)\end{array}$ & $\begin{array}{l}\text { Stapled anastomosis } \\
\qquad(n=35)\end{array}$ & $p$ value \\
\hline Age (years); mean $\pm S D$ & $61.1 \pm 13.5$ & $60.7 \pm 13.0$ & $61.9 \pm 14.5$ & 0.44 \\
\hline \multicolumn{5}{|l|}{ Gender; n (\%) } \\
\hline Male & $53(52.5)$ & $34(51.5)$ & $19(54.2)$ & \\
\hline Female & $48(47.5)$ & $32(48.5)$ & $16(45.8)$ & \\
\hline $\mathrm{BMI}\left(\mathrm{kg} / \mathrm{m}^{2}\right) ;$ mean $\pm \mathrm{SD}$ & $27.7 \pm 4.5$ & $28.0 \pm 4.5$ & $27.2 \pm 4.3$ & 0.65 \\
\hline Smoker; n (\%) & $31(30.6)$ & $22(33.3)$ & $9(25.7)$ & 0.43 \\
\hline $\mathrm{CCl} ; \mathrm{n}(\%)$ & & & & 0.011 \\
\hline 0 & 55 (54.4) & $42(63.6)$ & $13(37.2)$ & \\
\hline$\geq 1$ & 46 (45.6) & $24(36.4)$ & $22(62.8)$ & \\
\hline NRS-2002 score; $n(\%)$ & & & & 0.16 \\
\hline 0 & 51 (50.4) & $30(45.5)$ & $21(60)$ & \\
\hline$\geq 1$ & $50(49.6)$ & $36(54.5)$ & $14(40)$ & \\
\hline Abdominal operation history; $\mathrm{n}(\%)$ & $21(20.7)$ & $14(21.2)$ & $7(20)$ & 0.88 \\
\hline FEV1 (\%); mean \pm SD & $95.3 \pm 19.6$ & $97.5 \pm 15.7$ & $91.0 \pm 25.1$ & 0.003 \\
\hline ASA grade; $n(\%)$ & & & & 0.28 \\
\hline $1-2$ & 39 & 28 & 11 & \\
\hline $3-4$ & 62 & 38 & 24 & \\
\hline Hematocrit (\%); mean \pm SD & $32.15 \pm 5.40$ & $33.12 \pm 5.51$ & $30.36 \pm 4.76$ & 0.33 \\
\hline Albumin; mean $\pm S D$ & $3.97 \pm 0.46$ & $3.99 \pm 0.48$ & $3.92 \pm 0.41$ & 0.53 \\
\hline C-reactive protein $>0,35 \mathrm{mg} / \mathrm{dl}$ (yes); $\mathrm{n}(\%)$ & $24(23.7)$ & $17(25.7)$ & $7(20)$ & 0.51 \\
\hline Creatinin $>1,0$ mg/dl (yes;) n (\%) & $16(15.8)$ & $12(18.1)$ & $4(11.4)$ & 0.37 \\
\hline
\end{tabular}

SD, standard deviation; BMI, body mass index; CCI, charlson comorbidity index; NRS-2002, nutrition risk screening-2002; ASA, American society anesthesiologists 
Table 2. Surgical procedure and postoperative course.

\begin{tabular}{|c|c|c|c|c|}
\hline & $\begin{array}{l}\text { Number of patients } \\
\qquad(n=101)\end{array}$ & $\begin{array}{l}\text { Hand-sewn anastomosis } \\
\qquad(\mathrm{n}=66)\end{array}$ & $\begin{array}{l}\text { Stapled anastomosis } \\
\qquad(\mathrm{n}=35)\end{array}$ & p value \\
\hline \multicolumn{5}{|l|}{ Surgical approach; n (\%) } \\
\hline Open & $81(80.1)$ & $57(86.3)$ & $24(68.5)$ & 0.033 \\
\hline Laparoscopic & 20 (19.9) & $9(13.7)$ & $11(31.5)$ & \\
\hline Procedure; n (\%) & & & & 0.71 \\
\hline Standard right hemicolectomy & $80(79.2)$ & $53(80.3)$ & $27(77.1)$ & \\
\hline Extended right hemicolectomy & $21(21.8)$ & $13(19.7)$ & $8(22.9)$ & \\
\hline \multicolumn{5}{|l|}{ Type of anastomoses; $\mathrm{n}(\%)$} \\
\hline End-to-side & $42(41.5)$ & $40(60.6)$ & $2(5.7)$ & $<0.001$ \\
\hline Side-to-side & $59(58.5)$ & $26(39.4)$ & $33(94.3)$ & \\
\hline Intraoperative transfusion (yes); n (\%) & $24(23.7)$ & $13(19.6)$ & $11(31.4)$ & 0.18 \\
\hline Surgical duration ( $\min$ ); mean $\pm S D$ & $189 \pm 57$ & $180.6 \pm 46.1$ & $204.8 \pm 71.3$ & $<0.001$ \\
\hline Complication (yes); n (\%) & $54(53.4)$ & $34(51.5)$ & $20(57.1)$ & 0.58 \\
\hline Anastomotic leak (yes); n (\%) & $3(2.97)$ & $1(1.5)$ & $2(5.7)$ & 0.23 \\
\hline Lenght of hospital stay (day); mean \pm SD & $9.9 \pm 5.9$ & $9.7 \pm 5.8$ & $10.3 \pm 6.1$ & 0.55 \\
\hline pT-stage; n(\%) & & & & 0.08 \\
\hline T1-T2 & $8(7.9)$ & $3(4.6)$ & $5(14.3)$ & \\
\hline T3-T4 & $93(92.3)$ & $63(95.4)$ & $30(85.7)$ & \\
\hline pN-stage; n (\%) & & & & 0.22 \\
\hline No & $58(57.4)$ & $35(53)$ & $23(65.7)$ & \\
\hline N1-2 & $43(42.6)$ & $31(47)$ & 12 (34.3) & \\
\hline Pathologic stage; n (\%) & & & & 0.54 \\
\hline $1-2$ & $56(55.6)$ & $34(51.5)$ & $22(62.8)$ & \\
\hline 3 & $41(40.5)$ & 29 (43.9) & $12(34.2)$ & \\
\hline 4 & $4(3.9)$ & $3(4.6)$ & $1(3)$ & \\
\hline
\end{tabular}

A laparoscopic approach was used in $19.9 \%$ of the patients. In total, $21.8 \%$ of the patients underwent an extended right hemicolectomy. Hand-sewn anastomosis most commonly performed for end-to-side anastomosis $(60.6 \%)$, and stapled anastomosis for side-to-side anastomosis $(94.3 \%)(p<0.001)$. There was no statistically significant difference between the groups in terms of intraoperative blood transfusions, postoperative complications and the results of pathological examinations. The operating time was longer in the stapled anastomosis group $(p<0.001)$. Anastomotic leakage developed in one patient in the hand-sewn (1.5\%) and in two patients in the stapled anastomosis group (5.7\%), however the difference between the groups was not statistically significant $(p=0.23)$. Details regarding surgery and patient outcomes are presented in Table 2.

Anastomotic leakage was detected in a total of three patients, without any relationship with advanced age, gender, operation time, laparoscopic approach, smoking status or anastomosis technique. Only intraoperative blood transfusion was found to be a risk factor for anastomotic leakage $(p=0.002)$. The data on anastomotic leakage is presented in Table 3.

Furthermore, two patients developed anastomotic leakage and underwent repeat surgery and an end ileostomy. Of these, one patient was followed up with a conservative approach, and the fistula in this patient closed spontaneously within 30 days of surgery.

One patient in the hand-sewn anastomosis group died within 30 days of surgery, however when compared to the stapled anastomosis group $(p=0.46)$, the difference between groups was not statistically significant. Furthermore, two patients in the hand- 
Table 3. Incidence and univariate analysis of factors associated with anastomotic leak.

\begin{tabular}{|c|c|c|c|}
\hline & $n$ & (\%) & p value \\
\hline \multicolumn{4}{|l|}{ Age; years } \\
\hline$<65$ & $2 / 56$ & $(3,5)$ & 0.691 \\
\hline$\geq 65$ & $1 / 45$ & $(2,2)$ & \\
\hline \multicolumn{4}{|l|}{ Gender } \\
\hline Male & $2 / 53$ & $(3,7)$ & 0.617 \\
\hline Female & $1 / 48$ & $(2)$ & \\
\hline \multicolumn{4}{|c|}{ Intraoperative blood transfusion } \\
\hline Yes & $3 / 24$ & $(12,5)$ & 0.002 \\
\hline No & $0 / 77$ & (0) & \\
\hline \multicolumn{4}{|c|}{ Operation time, $\min$} \\
\hline$\geq 192$ & $2 / 34$ & $(5,8)$ & 0.219 \\
\hline$<192$ & $1 / 67$ & $(1,5)$ & \\
\hline \multicolumn{4}{|l|}{ Surgical approach } \\
\hline Open & $2 / 81$ & $(2,4)$ & 0.550 \\
\hline Laparoscopic & $1 / 20$ & (5) & \\
\hline \multicolumn{4}{|c|}{ Abdominal operation history } \\
\hline No & $3 / 80$ & $(3,7)$ & 0.368 \\
\hline Yes & $0 / 21$ & $(0)$ & \\
\hline \multicolumn{4}{|l|}{$\mathrm{CCl} \geq 1$} \\
\hline No & $1 / 55$ & $(1,8)$ & 0.456 \\
\hline Yes & $2 / 46$ & $(4,3)$ & \\
\hline \multicolumn{4}{|l|}{ Smoker } \\
\hline No & $3 / 70$ & $(4,2)$ & 0.242 \\
\hline Yes & $0 / 31$ & (0) & \\
\hline \multicolumn{4}{|c|}{ Anastomotic technique } \\
\hline Hand-sewn & $1 / 66$ & $(1,5)$ & 0.237 \\
\hline Stapled & $2 / 35$ & $(5,7)$ & \\
\hline \multicolumn{4}{|c|}{ Type of anastomoses } \\
\hline End-to-side & $1 / 42$ & $(2,3)$ & 0.768 \\
\hline Side-to-side & $2 / 59$ & $(3,3)$ & \\
\hline
\end{tabular}

CCl: charlson comorbidity index

sewn anastomosis group died within 6 months of surgery, while no mortality was recorded in the stapled anastomosis group, and again the difference between the two groups was not statistically significant $(p=0.29)$.

\section{DISCUSSION}

The present study shows that neither the stapled nor hand-sewn ileocolic anastomosis approach to the treatment of right colon cancer poses a risk for the development of anastomotic leakage. The overall rate of anastomotic leakage was $2.9 \%$ in the study, and the use of stapler did not increase the rate of anastomotic leakage. A statistical analysis identified only intraoperative blood transfusion as being related to the development of anastomotic leakage. A homogeneous group was created in our study to include only patients with right colon cancer. All operations were performed with the purpose of achieving a cure, and in line with oncological principles.

There is a lack of consensus in the literature regarding the stapled ileocolic anastomosis. In a Cochrane review of 955 patients undergoing ileocolic anastomosis in 2007, stapled end-to-end anastomosis was reported to reduce the risk of anastomotic leakage, and the use of a stapler, as a popular approach at the time in surgical interventions, prevails today ${ }^{(16)}$. The same study did not identify any difference between the groups in terms of other anastomotic complications. Today, the situation is reversed for ileocolic anastomosis, which has been associated with low rates of anastomotic leakage, while the use of stapler is regularly implicated in anastomotic leakage. Some recent studies have suggested that the use of stapler in ileocolic anastomosis increases the risk of anastomotic leakage $(6,10,17,18)$.

Aside from the anastomosis technique, male gender, smoking status and intraoperative blood transfusion were also identified as risk factors for anastomotic leakage following right hemicolectomy ${ }^{(12,17)}$. In a Swedish study on a large series of patients, Gustafsson et al. reported male gender and emergency surgery, in addition to stapled anastomosis to be the risk factors for anastomotic leakage after ileocolic anastomosis. Similarly, a Danish study involving 1,414 patients reported anastomotic leakage in $3.2 \%$ of patients, while smoking and the stapled anastomosis approach were identified as risk factors for anastomotic leakage ${ }^{(12)}$. The present study evaluated smoking status, operation time and Charlson's comorbidity index and their relationship with healing following anastomosis, and found that while these parameters may be risky for wound healing, they did not pose a risk for anastomotic leakage.

Different risk factors have been identified for anastomotic leakage in ileocolic anastomosis in various studies, and the stapled anastomosis technique has been most commonly implicated. Stapled anastomosis is an accepted technique worldwide due to its ease of use, while the use of the stapled approach in 
ileocolic anastomosis has been linked to the development of anastomotic leakage. However any explanation has not yet been provided as to how it increases the rate of anastomotic leakage ${ }^{(12)}$. Although these studies include large patient groups, they cannot be regarded as a substitute for randomized and controlled trials. The same study also found that long-term survival is independent of the anastomosis technique, which was corroborated by a further study ${ }^{(19)}$. A few studies, however, have reported the benefits of stapled anastomosis regarding overall survival ${ }^{(20)}$. The present study, therefore, has evaluated survival in the short term rather than in the long term. It was noted that the use of a stapler had no effect either on the development of anastomotic leakage or mortality in the short term (postoperative 1 and 6 months).

The present study has some limitations, the first of which is its retrospective design, because the anastomosis technique is selected by the surgeon based on the condition of the patient. Dividing the patients into stapled and hand-sewn anastomosis groups can be seen as a simple grouping technique, however other data related to the anastomosis technique is reported in the present study. The number of patients was relatively low when compared to the large series assessed in previous studies, and a logistic regression analysis was not possible due to the low rates of anastomotic leakage.

The present study shows that the use of stapler in ileocolic anastomosis procedures following a right hemicolectomy does not increase the risk of anastomotic leakage, and has not any unfavorable effect on mortality in the short term. In contrast to the recent studies implicating the stapled approach in anastomotic leakage, the present study suggests that a stapler may be used in ileocolic anastomosis. That said, the authors believe that randomized and controlled studies are required to obtain more reliable data.

Ethics Committee Approval: The study was approved by the local ethics committee of the hospital (number 2019.2/10-161).

Funding: None

Conflict of interest: None

Informed Constent: Not applicable

\section{REFERENCES}

1. Bakker IS, Grossmann I, Henneman D, Havenga K, Wiggers T. Risk factors for anastomotic leakage and leak-related mortality after colonic cancer surgery in a nationwide audit. $\mathrm{Br} J$ Surg. 2014;101(4):424-32. https://doi.org/10.1002/bjs.9395

2. Krarup PM, Nordholm-Carstensen A, Jorgensen LN, Harling H. Anastomotic leak increases distant recurrence and long-term mortality after curative resection for colonic cancer: a nationwide cohort study. Ann Surg. 2014;259(5):930-8. https://doi.org/10.1097/SLA.0b013e3182a6f2fc

3. Takahashi $\mathrm{H}$, Haraguchi $\mathrm{N}$, Nishimura J, Hata T, Yamamoto $\mathrm{H}$, Matsuda C, et al. The Severity of anastomotic leakage may negatively impact the long-term prognosis of colorectal cancer. Anticancer Res. 2018;38(1):533-9. https://doi.org/10.21873/anticanres.12255

4. Jestin P, Pahlman L, Gunnarsson U. Risk factors for anastomotic leakage after rectal cancer surgery: a case-control study. Colorectal Dis. 2008;10(7):715-21. https://doi.org/10.1111/j.1463-1318.2007.01466.x

5. Matthiessen P, Hallbook O, Andersson M, Rutegård J, Sjödah R. Risk factors for an astomotic leakage after anterior resection of the rectum. Colorectal Dis. 2004;6(6):462-9. https://doi.org/10.1111/j.1463-1318.2004.00657.x

6. Jessen M, Nerstrøm M, Wilbek TE, Roepstorff S, Rasmussen MS, Krarup PM. Risk factors for clinical anastomotic leakage after right hemicolectomy. Int J Colorectal Dis. 2016;31(9): 1619-24. https://doi.org/10.1007/s00384-016-2623-5

7. Aday U, Gundes E, Ciyiltepe H, Cetin DA, Deger KC, Gulmez S, et al. Does antiaggregant administration lead to early diagnosis in proximal colon cancer? North Clin Istanb. 2017;4(2):173-9. https://doi.org/10.14744/nci.2017.80148

8. Pramateftakis MG, Vrakas G, Hatzigianni P, Tsachalis $T$, Matzoros I, Christoforidis E, et al. The hand sewn anastomosis after colon resection due to colonic cancer. Tech Coloproctol. 2010;14 Suppl 1:S57-9. https://doi.org/10.1007/s10151-010-0612-1

9. García-Granero E, Navarro F, CerdánSantacruz C, Frasson M, García-Granero A, Marinello F, et al. Individual surgeon is an independent risk factor for leak after double-stapled colorectal anastomosis: An institutional analysis of 800 patients. Surgery. 2017;162(5):1006-16. https://doi.org/10.1016/j.surg.2017.05.023

10. Frasson M, Granero-Castro P, RamosRodríguez JL, Flor-Lorente B, Braithwaite M, MartíMartínez E, et al. Risk factors for anastomotic leak and postoperative morbidity and mortality after elective right colectomy for cancer: results from a prospective, multicentric study of 1102 patients. Int J Colorectal Dis. 2016;31(1):105-14. https://doi.org/10.1007/s00384-015-2376-6

11. Choy PY, Bissett IP, Docherty JG, Parry BR, Merrie A, Fitzgerald A. Stapled versus hand sewn methods for ileocolic anastomoses. Cochrane Database Syst Rev. 2011;(9):CD004320. https://doi.org/10.1002/14651858.CD004320.pub3

12. Nordholm-Carstensen A, SchnackRasmussen M, Krarup PM. Increased leak rates following stapled versus hand sewn ileocolic anastomosis in patients with right-sided colon cancer: a nationwide cohort study. Dis Colon Rectum. 2019;62(5): 542-8. https://doi.org/10.1097/DCR.0000000000001289

13. Steichen FM. The use of staplers in anatomical side-to-side and functional end-to-end enteroanastomoses. Surgery. 1968:64(5):948-53. PMID: 5687844.

14. Meagher AP, Wolff BG. Right hemicolectomy with a linear cutting stapler. Dis Colon Rectum. 1994;37(10):1043-5. https://doi.org/10.1007/BF02049322

15. Charlson M, Wells MT, Ullman R, King F, Shmukler C. The 
Charlson comorbidity index can be used prospectively to identify patients who will incur high future costs. PLoS One. 2014;9(12):e112479.

https://doi.org/10.1371/journal.pone.0112479

16. Choy PY, Bissett IP, Docherty JG, Parry BR, Merrie AE. Stapled versus hand sewn methods for ileocolic anastomoses. Cochrane Database Syst Rev. 2007;(3):CD004320. https://doi.org/10.1002/14651858.CD004320.pub2

17. Gustafsson P, Jestin P, Gunnarsson U, Lindforss U. Higher frequency of anastomotic leakage with stapled compared to hand sewn ileocolic anastomosis in a large population-based study. World J Surg. 2015;39(7):1834-9. https://doi.org/10.1007/s00268-015-2996-6

18. 2015 European Society of Coloproctology collaborating group. The relationship between method of anastomosis and anas- tomotic failure after right hemicolectomy and ileo-caecal resection: an international snapshot audit. Colorectal Dis. 2017;19(8):e296-311.

https://doi.org/10.1111/codi.13646

19. Wolmark N, Gordon PH, Fisher B, et al. A comparison of stapled and hand sewn anastomoses in patients undergoing resection for Dukes' B and C colorectal cancer. An analysis of disease-free survival and survival from the NSABP prospective clinical trials. Dis Colon Rectum. 1986;29(5):344-50.

https://doi.org/10.1007/BF02554128

20. Akyol AM, McGregor JR, Galloway DJ. Recurrence of colorectal cancer after sutured and stapled large bowel anastomoses. Br J Surg. 1991;78(11):1297-300. https://doi.org/10.1002/bjs.1800781107 